\title{
Effect of different environmental condition on different types of Sweet lime cuttings
}

\author{
Ibrar Hussain ${ }^{1 *}$, Ghulam Nabi ${ }^{2}$, Hafeez ur Rehman ${ }^{1}$, Kamran Shah $^{1}$ and \\ Saqib $\mathrm{Ali}^{2}$ \\ 1. Agriculture Research Institute, Tarnab, Peshawar, Pakistan \\ 2. The University of Agriculture Peshawar, Pakistan \\ *Corresponding author's email: ibrar_horti@yahoo.com \\ Citation \\ Ibrar Hussain, Ghulam Nabi, Hafeez ur Rehman, Kamran Shah and Saqib Ali. Effect of different environmental \\ condition on different types of Sweet lime cuttings. Pure and Applied Biology. Vol. 5, Issue 2, 2016, pp298-302. \\ http://dx.doi.org/10.19045/bspab.2016.50038
}

Received: 12/01/2016

Revised: 01/03/2016

Accepted: 08/03/2016

Online First: 21/03/2016

\section{Abstract}

The experiment on the effect of different environmental condition on different types of sweet lime cutting was carried out at Agriculture Research Institute Tarnab, Peshawar, Pakistan in 2010-11. The experiment was laid out in Randomized Complete Block Design (RCBD) with four replications. Three different cutting types i.e. tip cutting, softwood and semi hardwood, were planted in three different environmental conditions i.e. Open field, plastic tunnel and shade house. The variables studied were number of roots per cutting, sprouting percentage, days to sprouting, number of sprouts cuttings, leaves per shoot. The results revealed that semi hardwood cuttings took minimum days to sprouting and maximum sprouting percentage and leaves per shoot. Soft wood cutting attained maximum roots per cutting and number of sprouts per cutting whereas tip cutting showed lowest sprouting percentage, sprouts per cutting, leaves per shoot and roots per cutting. In case of the environmental conditions, the cutting planted in plastic tunnel showed maximum roots per cutting, sprouting percentage, sprouts per cutting, leaves per shoot and minimum days to sprouting. While the cuttings planted in open field showed minimum roots per cutting, sprouting percentage, sprouts per cutting, leaves per shoot, and maximum days to sprouting. It is concluded that planting Semi hardwood or softwood performs best under plastic tunnel.

Key words: Propagation; Softwood cutting; Plastic pavilion; Citrus limettioides

\section{Introduction}

The sweet lime, (Citrus limettioides) belongs to family Rutaceae. The botanists refer it as native to India [1]. In Pakistan citrus are produced throughout the country whereas Punjab contributes $95 \%$ of the total production. The tree, its foliage, and the form and size of the fruit resemble the Tahiti lime; the leaves are serrated and the petioles nearly wingless. The flowers are borne singly in the leaf axils or in terminal clusters of 2 to 10; the fruits may be solitary or in bunches of 2 to 5 . The sweet lime is selfcompatible, however cross pollination with sweet orange or grape fruit results in greater fruit retention. The sweet lime is grown 
from cuttings. Though seeds germinate readily and there is considerable existence of polyembrony too in sweet lime, but still people prefer to plant asexually raised plants.

Fruits plants are normally produced through vegetative propagation i.e. grafting, budding, layering and cutting. Using of cuttings from stems, leaves, roots and terminal buds is consider as most popular technique for most of the horticultural plants in almost all part of the world. while success of the cuttings depends mainly on the physiological stage of the mother plant [2], the time of planting cuttings $[3,4]$ and the type of growth regulators used [5] and all these in term depends on the prevailing environmental condition i.e. temperature, humidity and light [6]. On other hand [7] studied the effect of the plastic pavilions on the propagation of woody stem cuttings of pomegranate, The result indicate that using plastic pavilion increased the temperature which promotes early callus formation of buds and roots in different types of Pomegranate cuttings in cold areas. Therefore the importance and feasibility of plastic pavillion the present study was carried out to evaluate different type of sweet lime cuttings under different type of environment for commercial production of sweet lime plants.

\section{Material and methods}

The experiment on the "Effect of different environmental conditions on different types of sweet lime cuttings" was carried out at Agriculture Research Institute Tarnab, Peshawar Pakistan from mid November to mid February. The cuttings were taken from stock plants on $15^{\text {th }}$ November, 2010 and were planted in plastic tube having mixed media of garden soil, farmyard manure and silt at a ratio of $1: 1: 1$. The experiment was laid out in Randomized Complete Block Design with four replications with 10 cuttings per plot, in a $3 \times 3$ factorial arrangements. The factors were three cutting types i.e. tip cutting, softwood and semi hardwood and different environmental conditions i.e. plastic tunnel, shade house and open.

The cuttings were collected from well established trees maintained at screen house, and tip cuttings, softwood and semi hardwood cuttings were prepared from different portion of each shoot. The length of each cutting was $10-12 \mathrm{~cm}$. The cuttings consisted of cut just below the node and the leaves near to the basal portion were removed, leaving a pair of leaves at the top for stem cuttings.

After 90 days the following variables were studied: Roots per cutting (number of roots emitted by each cutting), Days to sprouting (number of days from the day of planting the cutting to the day of sprouting the first bud on the cutting), Sprouting percentage (Percentage of sprouted cuttings), number of sprouts per cutting and leaves per shoot (total number of leaves on new sprouted shoots). All the recorded data were statistically analyzed using analysis of variance and the means were compared using LSD test, when the F-values were significant [8]. The data were analyzed using statistical software MSTATC (Michigan State University).

\section{Results and discussion Number of roots per cutting}

Type of cutting and environmental conditions had a significant effect on number of roots per cutting. In case of cutting types, maximum (15.25) roots per cutting were observed in softwood followed by semi hardwood cuttings (14.36), while minimum (13.33) were recorded in tip cuttings, the results are in accordance with [9], who states that Carbohydrate and Nitrogen ratio had positive impact on the number of roots produced by plants propagated through cuttings in tetraploid locust plant. In case of environmental 
conditions, maximum (18.61) roots per cutting were observed in the cuttings that were planted in plastic tunnel while minimum (11.65) roots per cutting were recorded in cuttings that were not covered. The Plastic tunnel had positive impact on the number of roots produced which is the same finding as that of [10] also [11] stated that plastic tunnel enhanced roots in shrubby plant Ixora coccinea due to high humidity and optimum temperature, which provided the proper micro environment needs for the initiation of roots.

\section{Days to sprouting}

Days to sprouting is significantly affected by different environmental condition while the type of cuttings and interaction between type of cutting and environment is nonsignificant. Semi hardwood cutting took minimum (55.66) days to sprouting followed by tip cutting (57.56) while softwood cuttings took minimum (58.88) days to sprouting. In case of different environmental condition minimum (39) days to sprouting was observed in cuttings planted in plastic tunnel followed by cuttings in shade house (64.44) while cuttings planted in open took maximum (67.77) days to sprouting. The better results in low plastic tunnel may be due to higher temperature and humidity than outside. The results are in line with [7] studied various types of pomegranate cuttings under different environment and [5] worked on Hamelia patens propagation under plastic tunnels states that light, temperature and humidity is considered as an important role in rooting and succeeding growth of cuttings.

\section{Sprouting percentage}

Sprouting percentage is significantly affected by different types of cutting and different environmental condition. Maximum (72.61\%) sprouting was recorded in semi hardwood cuttings followed by softwood cutting (68.83\%), while minimum $(66.67 \%)$ was recorded in tip cutting. The results are in accordance with [12] who states that hardwood cuttings of platanus orientalis had higher percentage of sprouted cuttings than tip cuttings due to high amount of stored carbohydrate in hardwood cuttings. While in case of environmental affect maximum sprouting (79.94\%) was observed in plastic covering while minimum $(58.30 \%)$ was observed in cuttings have no covering material. The findings are in line with [7] who state that due appropriate conditions i.e. humidity and temperature provided for cuttings in low plastic tunnel increase the sprouting percentage than open environment.

\section{Sprouts per cutting}

Number of sprouts per cutting significantly affected by different types of cutting and different environmental condition while the interaction between type of cutting and environment was non-significant. In case of different types of cutting highest number of sprouts per cutting (6.63) was attained by sweet lime propagated through soft wood cutting followed by semi hardwood cutting (6.34) while minimum (5.02) was observed in tip cutting. The number of sprouts varied due to the variation in number of roots which in turn effect the water and nutrients supply after the initial sprouting, whereas in case of environment highest (7.80) number of sprouts was observed in cuttings placed in plastic tunnel whereas lower number of sprouts (4.73) observed in open. The results are in accordance with [13] whom states that using plastic pavilion for fig propagation increased the temperature that promotes early callus formation of buds and roots in the propagation through cutting in colder areas.

\section{Leaves per shoot}

Number of leaves per shoot were significantly affected by different types of environment used for sweet lime cuttings however the effect of types of cutting and the interaction of type of cuttings and 
environmental conditions was nonsignificant. In case of cutting types, maximum (4.56) leaves per shoot were observed in semi hardwood cuttings, while minimum (4.38) was observed in Tip cutting. In case of the environmental conditions, maximum (5.32) leaves per shoot were produced by the cuttings planted in Plastic tunnel, while minimum (4.07) leaves per shoot were observed in cuttings planted in shade house. The [14] states that plastic tunnel had positive impact on the number of leaves produced on Quisqualis indica cutting planted in plastic tunnel then without low plastic tunnel. These results emphasize the positive relationship between growth of the leaves and humidity, which is similar to that obtained by [4] in Ficus retusa (Table 1).

Table 1. Effect of different environmental condition on different type of cutting on number of roots per cutting, days to sprouting, sprouting percentage, sprouts per cutting and number of leaves

\begin{tabular}{lccccc}
\hline $\begin{array}{l}\text { Cutting } \\
\text { type(C) }\end{array}$ & $\begin{array}{c}\text { Roots per } \\
\text { cutting }\end{array}$ & $\begin{array}{c}\text { Days to } \\
\text { Sprouting }\end{array}$ & $\begin{array}{c}\text { Sprouting } \\
\text { percentage }\end{array}$ & $\begin{array}{c}\text { Sprouts per } \\
\text { cutting }\end{array}$ & $\begin{array}{c}\text { Leaves per } \\
\text { shoot }\end{array}$ \\
\hline Tip & $13.33 \mathrm{~B}$ & 57.56 & $66.67 \mathrm{~B}$ & $5.02 \mathrm{~B}$ & 4.38 \\
Soft wood & $15.25 \mathrm{~A}$ & 58.00 & $68.83 \mathrm{AB}$ & $6.63 \mathrm{~A}$ & 4.53 \\
Semihardwood & $14.36 \mathrm{AB}$ & 55.67 & $72.61 \mathrm{~A}$ & $6.34 \mathrm{~A}$ & 4.56 \\
\hline Significance & $*$ & $\mathrm{~ns}$ & $*$ & $*$ & $\mathrm{~ns}$ \\
\hline LSD & 1.165 & & 4.742 & 0.758 & \\
\hline Environment(E) & & & & & \\
\hline Open & $11.69 \mathrm{~B}$ & $67.77 \mathrm{~A}$ & $58.31 \mathrm{C}$ & $4.73 \mathrm{C}$ & $4.08 \mathrm{~B}$ \\
Plastic tunnel & $18.61 \mathrm{~A}$ & $39.00 \mathrm{~B}$ & $79.94 \mathrm{~A}$ & $7.81 \mathrm{~A}$ & $5.32 \mathrm{~A}$ \\
Shade House & $12.64 \mathrm{~B}$ & $64.44 \mathrm{~A}$ & $69.86 \mathrm{~B}$ & $5.46 \mathrm{~B}$ & $4.07 \mathrm{~B}$ \\
\hline Significance & $*$ & $*$ & $*$ & $*$ & $*$ \\
\hline LSD & 4.1627 & 0.289 & 1.165 & 1.309 & 0.58 \\
\hline Interaction & $\mathrm{ns}$ & $\mathrm{ns}$ & $\mathrm{ns}$ & $\mathrm{ns}$ & $\mathrm{ns}$ \\
(CxE) & & & & & \\
\hline
\end{tabular}

Means followed by the same letter are non-significant at 5\% level of significance, using LSD test at 5\% level of significance

\section{Conclusion}

Among different type of cuttings, the softwood and semi hardwood showed optimum results for number of roots, sprouting percentage and number of sprouts per cutting. Sweet Lime cuttings planted in plastic pavilion showed significant performance in terms of number of roots per cutting, days to sprouting, sprouting percentage, number of sprouts and leaves per shoot. Based on the findings it is concluded that planting Semi hardwood or softwood cuttings performs best under plastic tunnel for commercial production of sweet lime plants.

\section{Authors' contributions}

Conceived and designed the experiments: I Hussain, Performed the experiments: I Hussain, G Nabi \& S Ali, Analyzed the data: S Kamran \& H Rehman, Contributed reagents/materials/ analysis tools: G Nabi \& H Rehman, Wrote the paper: I Hussain \& S Ali.

\section{References}

1. Milind SL (2008). Citrus Fruit: Biology, Technology and Evaluation 28.

2. Day JS \& Loveys BR (1998). Propagation from cuttings of two woody ornamental Australian shrubs, Boronia megastigma and Hypocalymma 
angustifolium, Endl. (White myrtle). Austral J Exper Agric 38: 201-206.

3. Hartmann HT \& Loreti F (1965). Seasonal variation in rooting of leafy olive cuttings under mist. Proc. American Soc Hort Sc 87: 98-194.

4. Darwesh RSS (2000). Studies on propagation of Ficus retusa cv. Hawii. M.Sc Thesis, Faculty of Agric., Cairo Univ. Egypt.

5. Elgimabi MENE (2009). Improvement of propagation by hardwood cuttings with or without using plastic tunnel in Hamelia patens. World J Agric. Sci 5(5): 522-524.

6. Fachinello JC \& Pauletto EA (1994). Influence of substrate on rooting of semihar wood cutting of fig. Rev Brasde Frutic 16(1): 302-307.

7. Hussain I, Mateen AK, Amin N, Aman F $\&$ Sajid M (2012). Response of different pomegranate cuttings types to different environmental conditions. Sarhad J Agric 28(1): 15-18.

8. Jan MT, Shah P, Hollington PA, Khan MJ \& Sohail Q (2009). Agriculture Research: Design and Analysis, a Monograph. Agric. Univ. Peshawar, Pakistan.
9. Xiao WL \& Zhong Z (2012). Seasonal variation in rooting of the cuttings from Tetraploid Locust in relation to nutrients and endogenous plant hormones of the shoot.Turk J Agric 36: 257-266.

10. Elgimabi MENE (2008). Effect of Season of Cutting and Humidity on Propagation of (Ixora coccinea). Advances in Biol Res 2(5-6): 108-110.

11. Dahab MA (1992). Production of ornamental plants. Cairo Press 6-8.

12. Sajid M, Pervaiz M, Rab A, Jan A, Haq I, Wahid F, Shah ST \& Ali I (2012). Response of plane tree (Platanus orientalis) to cuttings and planting dates. J Anim Plant Sci 22: 2.

13. Pipattanawong N, Tiwong S, Thongyean B, Darak R, Thamin P \& Techa W (2008). Improvement of propagation by hardwood cuttings with and without using Plastic Pavilions in Fig (Ficus caricaL.). Kasetsart J Nat Sci 42: 207-214.

14. Elgimabi MENE (2009). Improvement of Propagation by Hardwood Cuttings With or Without Using Plastic Tunnel in (Quisqualis indica). Advances in Biol Res 3(1-2): 16-18. 